\title{
MANAGEMENT OF SURFACE IRRIGATION ON WHEAT YIELD IN OLD VALLEY
}

\section{Bondok .M.Y* and EL- Sharkawey.A.F*}

\section{ABSTRACT}

Two field experiments were carried out at Gemmeiza Agric. Res. Station during winter (2012/2013 and 2013/2014) seasons to study the effect of three irrigation intervals (every 30, 40 and 50 days), farmyard manure (with and without farmyard manure) and three nitrogen fertilizer levels (40, 60 and $80 \mathrm{~kg} \mathrm{~N} / \mathrm{fed}$ ) on wheat yield, yield components and water use efficiency of wheat. A split - split plot design with three replication was used. The most important results could be summarized as followed. Due to irrigation every 30 days the plant height, straw yield (ton /fed), spike height.No. of grains /spike and grain yield (Mg/fed) were increased. the water use efficiency was decreased. Using farmyard manure increase the plant height, straw yield (ton/fed), spike height.No. of grains /spike, grain yield ( $\mathrm{Mg} / \mathrm{fed})$ and water use efficiency compared to without farmyard manure. By increasing fertilization $N$ levels increase both plant height, straw yield ( ton/fed), spike height.No. of grains /spike, grain yield (Mg/fed) and water use efficiency were increased .Interactions between irrigation interval 30 days, with farmyard manure and fertilization level $80 \mathrm{~kg} N / f e d$. could be recommended to obtain the best results of wheat yield.

Keywords: irrigation intervals, farmyard manure, fertilization N levels and WUE.

\section{INTRODUCTION}

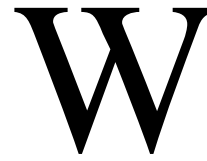

heat is the world's second major staple crop behind rice, and its cultivation also consumes a great deal of the world's water. Around $20 \%$ of the global wheat crop is now irrigated, according to current estimates, reaching at least 75 to $80 \%$ in countries Irrigation management is about controlling the rate, amount, and when applied irrigation water in a planned and efficient manner.

*Agric. Eng. Res. Instit.,Dokki, Giza, Egypt. 
With good irrigation management, a winter wheat crop can have high yield and quality potential. Scarcity and growing competition for fresh water resource will reduce its availability for irrigation. At the same time, the need to meet the growing demand for food will require increased crop production using less water. Regulated deficit irrigation provides a means of reducing water consumption while minimizing adverse effects on yield. The reported study was undertaken to determine an efficient strategy for management of irrigated wheat under water stressed conditions, in a sub-tropical sub-humid region. At the same time, water is becoming scarcer worldwide, and in fact a lack of water is already limiting wheat growth and yield in several regions of the world.

Irrigating wheat crop based on the physiological stags is one of the most important recommended methods of scheduling irrigation. If the water available is adequate then irrigation should be given at all the stages. However, if water is in short supply then irrigations should be given at certain critical (crown root initiation and flowering) stages. Maximum reduction would occur if the irrigation at the critical growth stage is missed. Therefore, if the water is available for less than adequate number (5-6) of irrigations then crop should be irrigated as below.

Moussa and Abdel- Maksoud( 2004 ) reported that, subjected wheat plants to drought- stress resulted in a significant reduction in grain yield, while the reduction in straw yield did not reach the significance level, regardless irrigation treatments, yield components i.e. number of spike $/ \mathrm{m}^{2}$, number of grains /spike and1000- grain weight seemed to be increased as the irrigation regime were increased .

Abou-khadrah et. al (1999) stated that the increase in straw yield as amount irrigation water increased might be due to the increase of yield components such as number of productive tillers and growth attributes.

Hefnawy and Wahba( 2003) reported that reducing the number irrigation , through skipping the late ones, resulted in higher WUEvalues for wheat crop .

Organic manures are recommended of soil properties mainly the physical ones and for increasing soil fertility. On the other land, mineral $\mathrm{N}$ fertilizers mainly nitrate $\mathrm{N}$ carriers, are costly and my lead to pollution of ground water. The consumption of $\mathrm{N}$ fertilizers is using year after due to 
the reclamation of new area and/or using high yield varieties. One of the main ways to overcome the shortage in the production of $\mathrm{N}$ fertilization is using the organic manure such as farmyard manure.Ali et . al (2008) found that , the yield of grains, and straw were increased by application of farmyard manure( FYM ) experiments. The 1000-grains weight increased by increasing nitrogen rate, using FYM and grain protein yield increased by $22.7 \%$ up on using FYM under sprinkler irrigation system and $37.5 \%$ under surface irrigation system

One the most important and practical practices to increase the efficiency of $\mathrm{N}$ fertilizers is the addition of the recommended amounts. It is quite known that nitrogen fertilization greatly affect wheat production. Hence, results of many researchers that achieved in Egypt revealed that nitrogen fertilizer. Levels significantly affected most of plant growth trails, yield and its components and the optimum nitrogen fertilizer level for wheat, vary widely in amounts ranged between 70 and $120 \mathrm{~kg} \mathrm{~N} / \mathrm{fed}$. According to environmental conditions (Tammam and Tawfils, 2004 )

Gehan et. al ( 2011) reported that ,all studied characters gradually increased by increasing nitrogen fertilizer levels from 35 to $105 \mathrm{~kg} \mathrm{~N} /$ fed.

El-Sayed et.al ( 2013 ) found that, wheat crop genotypes responded differently to the three factors for various characters . plant height, number of tillers $/ \mathrm{m} 2$, biological yield and straw yield produced the highest values at sowing 25 November as well as at $100 \mathrm{~kg} \mathrm{~N} / \mathrm{fed}$., The lowest values at $50 \mathrm{~kg} \mathrm{~N} / \mathrm{fed}$.

Qi Wang et. al (2012) who found that the largest straw yield per unit area was obtained by application of $100-150 \mathrm{Kg} \mathrm{N} / \mathrm{fad}$

The current study was carried out to investigate the effect of nitrogen fertilizers levels, with and without adding farmyard manure under three irrigation intervals on wheat yield and yield components, straw and water use efficiency .

\section{MATERIALS AND METHODS}

Two field experiments were executed during winter 2012/2013 and 2013/2014seasons at Gemmeiza Agricultural Research Station, ARS Gharbia Governorate, to study the effect of irrigation intervals 
,farmyard manure and nitrogen fertilizer levels on growth, yield and water utilization as well. The experimental soil is clay in texture as shown in Table (1)

Table (1) : Mechanical analysis and some soil moisture contents of the studied soil experimental.

\begin{tabular}{|l|l|l|l|l|l|l|l|}
\hline $\begin{array}{c}\text { Depth } \\
\mathrm{cm}\end{array}$ & $\begin{array}{c}\text { Fine } \\
\text { sand\% }\end{array}$ & $\begin{array}{c}\text { Coarse } \\
\text { Sand } \%\end{array}$ & Silt\% & Clay\% & $\begin{array}{l}\text { Soil } \\
\text { texture }\end{array}$ & FC.\% & W.P.\% \\
\hline $0-15$ & 3.90 & 19.80 & 27.00 & 49.30 & clay & 42.60 & 23.50 \\
\hline $15-30$ & 3.85 & 20.65 & 26.00 & 49.50 & clay & 41.10 & 22.60 \\
\hline $30-45$ & 3.95 & 20.40 & 29.30 & 46.35 & clay & 40.70 & 21.10 \\
\hline $45-60$ & 4.75 & 20.85 & 29.29 & 45.20 & clay & 40.00 & 20.50 \\
\hline
\end{tabular}

The experiments were carried out in a split split - plot design with three replications. The main plots were irrigation intervals ( every 30 days I1, every 40 days $\mathrm{I} 2$ and evey50 days $\mathrm{I} 3$ ), the sub -plots were farmyard manure FYM( with and without FYM) and sub -sub plots were devoted to $\mathrm{N}$-fertilizer levels ( 40,60 and $80 \mathrm{~kg} \mathrm{~N} / \mathrm{fed}$. ). The sub-sub plot area was $20 \mathrm{~m}^{2}$ ( 4 X $\left.5 \mathrm{~m}\right)$

Sowing date on $21^{\text {th }}$ November in the $1^{\text {st }}$ and $2^{\text {nd }}$ seasons .The common agricultural practices for growing wheat according to recommendations of Ministry of Agricultural were followed except the factors under study. At harvesting time, ten guarded plants of one square meter were randomly selected from each sub- sub plot to estimate the following characters.

1-Number of grains / spike

2-1000-grain weight ( gm )

3 -Grain yield ( $\mathrm{Mg} / \mathrm{fed}$.) calculated by harvesting plants in one square meter taken from each sub- sub plot and were left to dry and grains were weighted .

4- Straw yield ( ton /fed.) . the straw yield resulted from the previous sample was weighted in $\mathrm{kg} / \mathrm{plot}$, then it was converted to ton / fed.

\section{Water calculation:}

The irrigation water was supplied to plots through a circular orifice of 10 $\mathrm{cm}$ diameter and its discharge rate was measured by using the equation of immersed orifice according to James (1988) as follows :

$$
\mathrm{Q}=0.61 \mathrm{KAH}^{1 / 2}
$$


Where,

$$
\begin{aligned}
& \mathrm{Q}=\text { orifice discharge }(1 / \mathrm{s}) \\
& \mathrm{A}=\text { the area of orifice opening }\left(\mathrm{cm}^{2}\right) \\
& \mathrm{H}=\text { head, over the orifice center }(\mathrm{m}) . \\
& \mathrm{K}=\text { Unit constant }\left(\mathrm{K}=0.443 \text { for } \mathrm{Q} \text { in } \mathrm{L} / \mathrm{sec}, \mathrm{A} \text { in } \mathrm{cm}^{2},\right. \\
& \quad \text { and } \mathrm{H} \text { in } \mathrm{m})
\end{aligned}
$$

\section{Water Use Efficiency (WUE):}

Water use efficiency for crop is the weight of grain yield produced per volume unit of applied water expressed as cubic meters of water (Michael, 1978).

\section{RESULTS AND DISCUSSIONS}

\section{Plant height:}

Plant height affected by irrigation intervals, farmyard manure fertilization levels and their interaction. Table (2) show that the tallest plant height $(109.83$ and $110.56 \mathrm{~cm})$ under irrigation every 30 days ( I1 ) in $1^{\text {st }}$ and $2^{\text {nd }}$ season respectively . While shortest plant height (100.07 and $100.61 \mathrm{~cm}$ ) under irrigation every 50 days ( $\left.\mathrm{I}_{3}\right)$ in $1^{\text {st }}$ and $2^{\text {nd }}$ season respectively , this data may be found suitable interval of plant during growing season under irrigation every 30 days( $I_{1}$ ), but when exposed to water deficit under irrigation every 40 days $\left(I_{2}\right.$ and 50days ( $\left.I_{3}\right)$ decrease plant height .

Plant height increased by application of farmyard manure ( FYM) compared with the without FYM treatment .It increased by about 3.66 and $3.55 \%$ in $1^{\text {st }}$ and $2^{\text {nd }}$ season respectively .

Nitrogen fertilization has a pronounced effect on plant height in both seasons. By increasing fertilizer level the plant height increased, tallest plants (106.46and $107.05 \mathrm{~cm}$ ) at $80 \mathrm{~kg} \mathrm{~N} / \mathrm{fed}$. , at $60 \mathrm{~kg} \mathrm{~N} / \mathrm{fed}$ plant height (104.84 and $105.78 \mathrm{~cm})$. While shortest plants (103.49 and 103.95 $\mathrm{cm}$ ) at $40 \mathrm{~kg} \mathrm{~N} / \mathrm{fed}$. in $1^{\text {st }}$ and $2^{\text {nd }}$ season respectively. These results may be due to the stimulation effect on interned elongation JavaidIqbal et. al (2012) report that .

Data in table (2) show effect of interactions between irrigation interval( I ) , farmyard manure (FYM ) and fertilization $\mathrm{N}$ levels on plant height, the tallest plants $(112.63 \mathrm{~cm}$ and $113.12 \mathrm{~cm}$ ) were observed at irrigation 
every 30 day ( I1 ), farmyard manure and fertilization level at $80 \mathrm{~kg} \mathrm{~N} /$ fed. In $1^{\text {st }}$ and $2^{\text {nd }}$ seasons receptively. While the shortest ( 96.06 and $96.11 \mathrm{~cm}$ ) with irrigation every 50 day ( I 3), without farmyard manure ( FMY ) and fertilization level $40 \mathrm{~kg} \mathrm{~N} / \mathrm{fed}$. In $1^{\text {st }}$ and $2^{\text {nd }}$ seasons of study.

Table (2): Plant height ( $\mathrm{cm}$ ) and straw yield ( ton/ fed. ) affected by irrigation intervals, farmyard, fertilization $\mathrm{N}$ levels and interaction in two seasons of study.

\begin{tabular}{|c|c|c|c|c|c|c|c|c|c|c|}
\hline \multirow[t]{2}{*}{ seasons } & \multirow{2}{*}{$\begin{array}{l}\text { Organic } \\
\text { manure }\end{array}$} & \multirow{3}{*}{ Irr.Inter. } & \multicolumn{4}{|c|}{ Plant height $(\mathrm{cm})$} & \multicolumn{4}{|c|}{ Straw yield ( ton / fed ) } \\
\hline & & & $\mathrm{I} 1$ & $\mathrm{I} 2$ & $\mathrm{I} 3$ & Mean & $\mathrm{I} 1$ & $\mathrm{I} 2$ & $\mathrm{I} 3$ & Mean \\
\hline & & & & & & & & & & \\
\hline \multirow{8}{*}{$\begin{array}{l}1^{\text {st }} \\
\text { season }\end{array}$} & \multirow{3}{*}{$\begin{array}{l}\text { With } \\
\text { FYM }\end{array}$} & $40 \mathrm{kgN} / \mathrm{fed}$ & 109.65 & 105.26 & 101.80 & 105.57 & 4.122 & 3.957 & 3.710 & 3.936 \\
\hline & & $60 \mathrm{kgN} / \mathrm{fed}$ & 111.51 & 107.05 & 102.31 & 106.96 & 4.331 & 4.158 & 3.898 & 4.129 \\
\hline & & $80 \mathrm{kgN} / \mathrm{fed}$ & 112.63 & 108.12 & 103.62 & 108.12 & 4.550 & 4.368 & 4.095 & 4.338 \\
\hline & & Mean & 111.26 & 106.81 & 102.58 & 106.88 & 4.334 & 4.161 & 3.901 & 4.134 \\
\hline & \multirow{3}{*}{$\begin{array}{l}\text { Without } \\
\text { FYM }\end{array}$} & $40 \mathrm{kgN} / \mathrm{fed}$ & 106.73 & 101.40 & 96.06 & 101.40 & 3.943 & 3.707 & 3.431 & 3.693 \\
\hline & & $60 \mathrm{kgN} / \mathrm{fed}$ & 108.12 & 102.71 & 97.31 & 102.71 & 4.101 & 3.855 & 3.568 & 3.841 \\
\hline & & $80 \mathrm{kgN} / \mathrm{fed}$ & 110.32 & 104.80 & 99.29 & 104.71 & 4.259 & 4.003 & 3.705 & 3.989 \\
\hline & & Mean & 108.39 & 102.97 & 97.55 & 102.94 & 4.101 & 3.855 & 3.568 & 3.841 \\
\hline \multirow{8}{*}{$\begin{array}{l}2^{\text {nd }} \\
\text { season }\end{array}$} & \multirow{3}{*}{$\begin{array}{l}\text { With } \\
\text { FYM }\end{array}$} & $40 \mathrm{kgN} / \mathrm{fed}$ & 110.81 & 106.38 & 101.95 & 106.38 & 4.241 & 4.071 & 3.817 & 4.071 \\
\hline & & $60 \mathrm{kgN} / \mathrm{fed}$ & 112.00 & 107.52 & 103.04 & 107.52 & 4.463 & 4.285 & 4.017 & 4.285 \\
\hline & & $80 \mathrm{kgN} / \mathrm{fed}$ & 113.12 & 108.60 & 104.07 & 108.60 & 4.671 & 4.484 & 4.204 & 4.484 \\
\hline & & Mean & 111.98 & 107.50 & 103.02 & 107.50 & 4.458 & 4.280 & 4.013 & 4.280 \\
\hline & \multirow{3}{*}{$\begin{array}{l}\text { Without } \\
\text { FYM }\end{array}$} & $40 \mathrm{kgN} / \mathrm{fed}$ & 106.89 & 101.55 & 96.11 & 101.52 & 4.031 & 3.829 & 3.507 & 3.789 \\
\hline & & $60 \mathrm{kgN} / \mathrm{fed}$ & 109.51 & 104.04 & 98.56 & 104.04 & 4.229 & 3.967 & 3.671 & 3.953 \\
\hline & & $80 \mathrm{kgN} / \mathrm{fed}$ & 111.01 & 105.56 & 99.91 & 105.50 & 4.450 & 4.183 & 3.872 & 4.168 \\
\hline & & Mean & 109.14 & 103.72 & 98.19 & 103.69 & 4.237 & 3.993 & 3.683 & 3.970 \\
\hline
\end{tabular}

\section{Straw Yield :}

Straw yield affected by irrigation intervals, farmyard manure fertilization levels and their interaction. Table ( 2 ) show that highest values ( 4.218 and $4.348 \mathrm{ton} /$ fed ) at irrigation every 30 day ( $\left.\mathrm{I}_{1}\right)$ in $1^{\text {st }}$ and $2^{\text {nd }}$ season respectively these results may be due to increase plant height. While the lowest values ( 3.734 and 3.848 ton / fed. ) in $1^{\text {st }}$ and $2^{\text {nd }}$ seasons 
respectively, by using irrigation every 50 day (I3). These results may be due to available water all plant stages. Abou-khadrah et al (1999) stated that the increase in straw yield as amount irrigation water increased may be due to the increase of yield components such as number of productive tillers and growth attributes.

Straw yield affected by farmyard manure, with farmyard increased by7.0 4 and $6.59 \%$ in $1^{\text {st }}$ and $2^{\text {nd }}$ seasons, respectively, compared to without farmyard manure, these results due to increase plant height .These results agreement with Ali et. al (2008) .

Straw yield increased by $(8.45,4.28$ and $9.15,4.79 \%)$ by using $80 \mathrm{~kg}$ $\mathrm{N} /$ fed. Compared to 40 and $60 \mathrm{~kg} \mathrm{~N} / \mathrm{fed}$.in $1^{\text {st }}$ and $2^{\text {nd }}$ seasons respectively.Theseresults agreement with Nitrogen fertilizer levels had effect on straw yield $80 \mathrm{Kg} \mathrm{N} /$ fad produced highest straw yield. These results are in harmony with Seiling et. al (2005)

Data in table (2) show interaction between treatments, the highest values were ( 4.550 and 4.671 ton/fed $)$ in $1^{\text {st }}$ and $2^{\text {nd }}$ seasons respectively observed by applied irrigation every 30 day ( I1), with farmyard manure and $80 \mathrm{~kg} \mathrm{~N} / \mathrm{fed}$. While lowest values were ( 3.431 and 3.507 ton / fed) observed in irrigation every 50 day ( I3) , without farmyard manure and $40 \mathrm{~kg} \mathrm{~N} / \mathrm{fed}$. These results my be due to deficit irrigation water, farmyard manure and $\mathrm{N}$ level. This might be due to the well utilization of nitrogen fertilizer in metabolism and meristic activity which improved growth characters such as plant highly. These results are in agreement with those obtained by anureekaurpannu and buttar (2010) and Qi Wang et al. (2012) who found that the largest straw yield per unit area was obtained by application of $100-150 \mathrm{Kg} \mathrm{N} / \mathrm{fed}$.

\section{Spike length :}

Spike length affected by irrigation intervals, farmyard manure, fertilization $\mathrm{N}$ levels and their interaction. Table(3) show that, when intervals decreased spike length increased .Due to use irrigation every30 day( $\left.\mathrm{I}_{1}\right)$ spike length increased by ( 4.36, 8.89 and $4.49,8.97 \%$ ) compared to interval 40 and 50 day in $1^{\text {st }}$ and $2^{\text {nd }}$ seasons respectively. Moreover ,the spike length with farmyard manure increased by 6.45 and $7.05 \%$ ) compared to without farmyard manure in $1^{\text {st }}$ and $2^{\text {nd }}$ ,respectively. 
Data in Table (3 ) show, also, that ,spike length increased by increasing $\mathrm{N}$ level, in $1^{\text {st }}$ and $2^{\text {nd }}$ seasons, the treatment of $80 \mathrm{~kg} \mathrm{~N} /$ fed. spike length increased by $9.82,5.57$ and $9.67,5.21 \%$ compared to 40 and60 $\mathrm{kg} \mathrm{N} /$ fed in $1^{\text {st }}$ and $2^{\text {nd }}$ seasons, respectively

Table (3 ): Spike length( $\mathrm{cm}$ )and No. of grains / spike affected by irrigation intervals, farmyard, fertilization $\mathrm{N}$ levels and interaction in two seasons of study.

\begin{tabular}{|c|c|c|c|c|c|c|c|c|c|c|}
\hline \multirow[t]{2}{*}{ seasons } & \multirow{2}{*}{$\begin{array}{l}\text { Organic } \\
\text { manure }\end{array}$} & \multirow{3}{*}{ Irr.Inter. } & \multicolumn{4}{|c|}{ Spike length $(\mathrm{cm})$} & \multicolumn{4}{|c|}{ No.of grains / Spike } \\
\hline & & & I1 & $\mathrm{I} 2$ & I3 & Mean & $\mathrm{I} 1$ & $\mathrm{I} 2$ & I3 & Mean \\
\hline & & & & & & & & & & \\
\hline \multirow{8}{*}{$\begin{array}{l}1^{\text {st }} \\
\text { season }\end{array}$} & \multirow{3}{*}{$\begin{array}{l}\text { With } \\
\text { FYM }\end{array}$} & $40 \mathrm{kgN} / \mathrm{fed}$ & 11.66 & 11.19 & 10.78 & 11.19 & 63.07 & 60.54 & 58.02 & 60.54 \\
\hline & & $60 \mathrm{kgN} / \mathrm{fed}$ & 12.22 & 11.73 & 11.00 & 11.65 & 65.89 & 58.45 & 60.62 & 61.65 \\
\hline & & $80 \mathrm{kgN} / \mathrm{fed}$ & 13.01 & 12.49 & 11.97 & 12.49 & 68.55 & 65.81 & 63.07 & 65.81 \\
\hline & & Mean & 12.30 & 11.80 & 11.25 & 11.78 & 65.84 & 61.60 & 60.57 & 62.67 \\
\hline & \multirow{3}{*}{$\begin{array}{l}\text { Without } \\
\text { FYM }\end{array}$} & $40 \mathrm{kgN} / \mathrm{fed}$ & 11.00 & 10.45 & 10.01 & 10.49 & 59.46 & 57.08 & 53.51 & 56.68 \\
\hline & & $60 \mathrm{kgN} / \mathrm{fed}$ & 11,56 & 11.04 & 10.51 & 11,04 & 63.43 & 60.26 & 57.09 & 60.26 \\
\hline & & $80 \mathrm{kgN} / \mathrm{fed}$ & 12.10 & 11.55 & 11.0 & 11.55 & 66.07 & 62.77 & 59.45 & 62.77 \\
\hline & & Mean & 11.55 & 11.01 & 10.51 & 11.03 & 62.99 & 60.04 & 56.68 & 59.90 \\
\hline \multirow{8}{*}{$\begin{array}{l}2^{\text {nd }} \\
\text { season }\end{array}$} & \multirow{3}{*}{$\begin{array}{l}\text { With } \\
\text { FYM }\end{array}$} & $40 \mathrm{kgN} / \mathrm{fed}$ & 11.78 & 11.31 & 10.84 & 11.31 & 61.80 & 58.67 & 55.62 & 58.70 \\
\hline & & $60 \mathrm{kgN} / \mathrm{fed}$ & 12.35 & 11.86 & 11.36 & 11.86 & 64.44 & 61.22 & 58.00 & 61.22 \\
\hline & & $80 \mathrm{kgN} / \mathrm{fed}$ & 13.10 & 12.58 & 12.05 & 12.58 & 67.13 & 63.77 & 60.42 & 63.77 \\
\hline & & Mean & 12.41 & 11.92 & 11.42 & 11.92 & 64.46 & 61.22 & 58.01 & 61.23 \\
\hline & \multirow{3}{*}{$\begin{array}{l}\text { Without } \\
\text { FYM }\end{array}$} & $40 \mathrm{kgN} / \mathrm{fed}$ & 11.11 & 19.55 & 10.00 & 10.55 & 64.15 & 61.59 & 59.02 & 61.59 \\
\hline & & $60 \mathrm{kgN} / \mathrm{fed}$ & 11.66 & 11.08 & 10.50 & 11.08 & 66.94 & 64.26 & 61.58 & 64.26 \\
\hline & & $80 \mathrm{kgN} / \mathrm{fed}$ & 12.22 & 11.61 & 11.00 & 11.61 & 69.73 & 66.94 & 64.15 & 66.94 \\
\hline & & Mean & 11.66 & 14.08 & 10.50 & 11.08 & 66.94 & 64.26 & 61.58 & 64.26 \\
\hline
\end{tabular}

\section{Number of grains / spike:}

Number of grain /spike affected by irrigation intervals, farmyard manure, fertilization $\mathrm{N}$ levels and their interaction.

Data in Table ( 3) show that the number of grains /spike increase by decrease irrigation intervals in all treatment of study, highest values by using I. Number of grains /spike increase by $5.59,8.99$ and 8.06, 11.99 $\%$ compared to $\mathrm{I} 2$ and $\mathrm{I} 3$ in $1^{\text {st }}$ and $2^{\text {nd }}$ seasons, respectively these results may be suitable interval in I1 these agreement with Ali ( 1997) who 
found that, the kernels number / spike were increased when irrigation increased from 3-4 irrigations.

The number of grains /spike with farmyard manure increases by 4.36 and $4,72 \%$ compared to without farmyard manure in $1^{\text {st }}$ and $2^{\text {nd }}$ seasons, respectively.

Moreover, increasing the fertilization $\mathrm{N}$ levels increase number of grains / spike. The treatment of $80 \mathrm{~kg} \mathrm{~N} /$ fed increases number of grains /spike by $8.83,5.18$ and $7.21,4.01 \%$ compared by fertilization of 40 and60 $\mathrm{kgN} /$ fed.in $1^{\text {st }}$ and $2^{\text {nd }}$ seasons respectively.

Number of grains /spike affected by interaction of all treatments. The highest values were 68.55 and 69.73grains/spikein two seasons under I1, with farmyard manure and fertilization Level $80 \mathrm{kgN} / \mathrm{fed}$

\section{0 -grain Weight ( gm ):}

1000 weight ( gm ) affected by irrigation intervals, farmyard manure, fertilization $\mathrm{N}$ levels and their interaction .

Data in Table(4)show that,1000 weight (gm)increase by decrease intervals between irrigation, highest values observed by using I1. Weight of 1000 grain ( gm ) increase by 4.29, 8.97 and 4,51, $8.99 \%$ compared to $\mathrm{I}_{2}$ and $\mathrm{I} 3$ in $1^{\text {st }}$ and $2^{\text {nd }}$ seasons, respectively.

Increase 1000 weight with farmyard manure compered to without farmyard manure, the increase were 5.64 and $4.84 \%$ in $1^{\text {st }}$ and $2^{\text {nd }}$ seasons respectively.

Increase 1000 grain weight ( $\mathrm{gm}$ ) by increase fertilization $\mathrm{N}$ levels from 40 to 60 and $80 \mathrm{~kg} \mathrm{~N} / \mathrm{fed}$. Highest values were 52.00 and 52.38 ( gm )by using $80 \mathrm{~kg} \mathrm{~N} /$ fed in the $1^{\text {st }}$ and $2^{\text {nd }}$ seasons respectively. Nitrogen fertilizer had a significant effect on 1000-grain weight $80 \mathrm{Kg} \mathrm{N} / \mathrm{fad}$ caused the heaviest grains. These results are in harmony with Allam (2005) .

1000 grain weight affected by interaction between treatments . The highest values were 55,63 and 55.99 (gm) due to interaction between irrigation every 30 day ( I1), FYM and fertilization level $80 \mathrm{~kg}$ N/fed. While lowest values were 45.31 and 45.91 (gm ) due interaction irrigation every 50 day, without FYM and $40 \mathrm{kgN} /$ fed 
Table ( 4 ): 1000- grain weigh ( gm ) and grain yield $\left(\mathrm{Mg} \mathrm{fed}^{-1}\right)$ affected by Irrigation intervals, farmyard, fertilization $\mathrm{N}$ levels and interaction in Two seasons of study.

\begin{tabular}{|c|c|c|c|c|c|c|c|c|c|c|}
\hline \multirow[t]{2}{*}{ seasons } & \multirow{2}{*}{$\begin{array}{l}\text { Organic } \\
\text { manure }\end{array}$} & \multirow{2}{*}{ Fer.Levels } & \multicolumn{4}{|c|}{1000 - grain weight $(\mathrm{gm})$} & \multicolumn{4}{|c|}{ 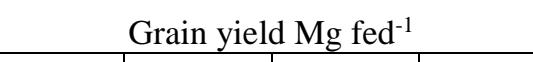 } \\
\hline & & & I1 & $\mathrm{I} 2$ & I3 & Mean & I1 & I2 & $\mathrm{I} 3$ & Mean \\
\hline \multirow{8}{*}{$\begin{array}{c}1^{\text {st }} \\
\text { season }\end{array}$} & \multirow{3}{*}{$\begin{array}{l}\text { With } \\
\text { FYM }\end{array}$} & $40 \mathrm{kgN} / \mathrm{fed}$ & 52.93 & 50.81 & 48,69 & 51.14 & 3.320 & 3.120 & 2.822 & 3.087 \\
\hline & & $60 \mathrm{kgN} / \mathrm{fed}$ & 53.87 & 51.72 & 49.56 & 51.72 & 3.488 & 3.314 & 2.965 & 3.255 \\
\hline & & $80 \mathrm{kgN} / \mathrm{fed}$ & 55.63 & 53.40 & 51.18 & 53.40 & 3.676 & 3.492 & 3.124 & 3.431 \\
\hline & & Mean & 54.14 & 51.98 & 49.81 & 52.09 & 3.428 & 3.309 & 2.970 & 3.257 \\
\hline & \multirow{3}{*}{$\begin{array}{c}\text { Without } \\
\text { FYM }\end{array}$} & $40 \mathrm{kgN} / \mathrm{fed}$ & 50.34 & 47.82 & 45.31 & 47.82 & 3.140 & 2.983 & 2.669 & 2.930 \\
\hline & & $60 \mathrm{kgN} / \mathrm{fed}$ & 51.63 & 49.05 & 46.47 & 49.05 & 3.265 & 3.102 & 2.775 & 3.048 \\
\hline & & $80 \mathrm{kgN} / \mathrm{fed}$ & 53.25 & 50.59 & 47.93 & 50.59 & 3.454 & 3.281 & 2.936 & 3.223 \\
\hline & & Mean & 51.74 & 49.15 & 46.57 & 49.15 & 3.286 & 3.122 & 2.793 & 3.067 \\
\hline \multirow{8}{*}{$\begin{array}{c}2^{\text {nd }} \\
\text { season }\end{array}$} & \multirow{3}{*}{$\begin{array}{l}\text { With } \\
\text { FYM }\end{array}$} & $40 \mathrm{kgN} / \mathrm{fed}$ & 53,00 & 50.88 & 48,76 & 50.88 & 3.390 & 3.255 & 2.916 & 3.187 \\
\hline & & $60 \mathrm{kgN} / \mathrm{fed}$ & 54.62 & 52.43 & 50.25 & 52.43 & 3.56 & 3.421 & 3.064 & 3.349 \\
\hline & & $80 \mathrm{kgN} / \mathrm{fed}$ & 55.99 & 53.75 & 51.51 & 53.64 & 3.745 & 3.595 & 3.220 & 5.20 \\
\hline & & Mean & 54.54 & 52.35 & 50.17 & 52.32 & 3.565 & 3.424 & 3.067 & 3.912 \\
\hline & \multirow{3}{*}{$\begin{array}{c}\text { Without } \\
\text { FYM }\end{array}$} & $40 \mathrm{kgN} / \mathrm{fed}$ & 51.01 & 48.46 & 45.91 & 48.46 & 3.200 & 3.072 & 2.720 & 2.997 \\
\hline & & $60 \mathrm{kgN} / \mathrm{fed}$ & 52.41 & 49.79 & 47.17 & 49.79 & 3.310 & 3.177 & 2.813 & 3.100 \\
\hline & & $80 \mathrm{kgN} / \mathrm{fed}$ & 53.80 & 51.11 & 48.42 & 51.11 & 3.501 & 3.361 & 2.976 & 3.280 \\
\hline & & Mean & 52.41 & 49.79 & 47.17 & 49.79 & 3.337 & 3.203 & 2.836 & 3.126 \\
\hline
\end{tabular}

\section{Grain yield( $\left.\mathrm{Mg}_{\text {fed }}{ }^{-1}\right)$ :}

Data in Table ( 4) show, grain yield affected by irrigation intervals, farmyard manure, fertilization levels $\mathrm{N}$ and their interaction .Grain yield decreases by increasing intervals, the percentage of decreasing were 5.16, 14.99 and 4.00, $14.48 \%$ compared to I2 and I3 in $1^{\text {st }}$ and $2^{\text {nd }}$ seasons, respectively. Increasing grain yield with increasing irrigation due to increase yield component such as number of grains /spike and 1000- grain weight. These results agreement with Moussa and AbdelMaksoud( 2004 ) . 
Due to using farmyard manure grain yield increase by5.85 and $6.76 \%$ compared to without farmyard manure in $1^{\text {st }}$ and $2^{\text {nd }}$ seasons respectively.These results agreement with Aliet. al (2008)

Grain yield affected by fertilization levels, grain yield increases by increasing fertilization levels from 40 to 60 and $80 \mathrm{~kg} \mathrm{~N} / \mathrm{fed}$. With $80 \mathrm{~kg}$ $\mathrm{N} /$ fed. grain yield increase by $9.56,3.28$ and $9.05,5.15 \%$ compared to fertilization levels 40 and $60 \mathrm{~kg} \mathrm{~N} / \mathrm{fed} . \mathrm{In} 1^{\text {st }}$ and $2^{\text {nd }}$ seasons, respectively,

Data in Table (4) show that the highest values of the grain yield were 3.676 and $3.745 \mathrm{Mg}$ fed $^{-1}$ due to interaction between irrigation every 30 day (I1), with farmyard fertilization level $80 \mathrm{~kg} \mathrm{~N} /$ fed. Lowest values (2.669 and $2.916 \mathrm{Mg} \mathrm{fed}^{-1}$ ) due to interaction between irrigation every 50 day , without farmyard manure and fertilization level $40 \mathrm{~kg} \mathrm{~N} / \mathrm{fed}$.

\section{Irrigation water :}

Irrigation water affected by irrigation intervals, farmyard manure and fertilization $\mathrm{N}$ levels . Data in Table ( 5 ) show that. Irrigation water decrease by increasing intervals, the percentage of decreasing were $11.02,19.92$ and $10.42,19.17 \%$ by using I 2 and I 3 compared to I1 in $1^{\text {st }}$ and $2^{\text {nd }}$ seasons respectively. These data due to decrease irrigation number in $\mathrm{I} 2$ and $\mathrm{I} 3$.

Due to using farmyard manure irrigation water decrease by 6.84 and 7.33 $\%$ compared to without farmyard manure in $1^{\text {st }}$ and $2^{\text {nd }}$ seasons, respectively

Irrigation water affected by fertilization levels, irrigation water increase by increasing fertilization levels from 40 to 60 and $80 \mathrm{~kg} \mathrm{~N} / \mathrm{fed}$. With 80 $\mathrm{kg} \mathrm{N} /$ fed. Irrigation water increase with $80 \mathrm{~kg} \mathrm{~N} /$ fed. by $7.30,3.54$ and $6.31,3.64 \%$ compared to fertilization levels 40 and $60 \mathrm{~kg} \mathrm{~N} / \mathrm{fed}$. In $1^{\text {st }}$ and $2^{\text {nd }}$ seasons respectively,

Data in Table (5 ) show that the highest values of water applied were 60.95 and $60.71 \mathrm{~cm}$. due to interaction between irrigation every 30 day (I1), without farmyard manure and Fertilization level $80 \mathrm{~kg} \mathrm{~N} / \mathrm{fed}$. Lowest values $(42.62$ and $43.81 \mathrm{~cm})$ due to interaction between irrigation every 50 day, with farmyard manure and fertilization level $40 \mathrm{~kg} \mathrm{~N} / \mathrm{fed}$. 
Table (5): Irrigation water $(\mathrm{cm})$ and water use efficiency of grain yield WUE $\left(\mathrm{kg} \mathrm{cm}^{-1}\right)$ affected by irrigation intervals and farmyard fertilization $\mathrm{N}$ levels and their interaction in two seasons of study.

\begin{tabular}{|c|c|c|c|c|c|c|c|c|c|c|}
\hline \multirow[t]{3}{*}{ Seasons } & \multirow{3}{*}{$\begin{array}{l}\text { Organic } \\
\text { manure }\end{array}$} & \multirow{3}{*}{$\begin{array}{l}\text { Fertilization. } \\
\text { levels }\end{array}$} & \multicolumn{4}{|c|}{ Irrigation water $(\mathrm{cm})$} & \multicolumn{4}{|c|}{$($ WUE $) \mathrm{kg} \mathrm{cm}^{-1}$} \\
\hline & & & \multicolumn{4}{|c|}{ Irrigation intervals } & \multicolumn{4}{|c|}{ Irrigation intervals } \\
\hline & & & $\mathrm{I} 1$ & $\mathrm{I} 2$ & $\mathrm{I} 3$ & Mean & $\mathrm{I} 1$ & $\mathrm{I} 2$ & $\mathrm{I} 3$ & Mean \\
\hline \multirow{8}{*}{$\begin{array}{l}1^{\text {st }} \\
\text { season }\end{array}$} & \multirow{3}{*}{$\begin{array}{l}\text { With } \\
\text { Farmyard } \\
\text { manure }\end{array}$} & $40 \mathrm{kgN} / \mathrm{fed}$ & 52.74 & 45.24 & 42.62 & 46.87 & 62.95 & 66.76 & 66.92 & 65.54 \\
\hline & & $60 \mathrm{kgN} / \mathrm{fed}$ & 53.93 & 47.62 & 44.52 & 48.69 & 64.69 & 67.20 & 67.27 & 66.87 \\
\hline & & $80 \mathrm{kgN} / \mathrm{fed}$ & 55.36 & 50.00 & 45.48 & 50.27 & 66.41 & 67.84 & 68.69 & 67.64 \\
\hline & & Mean & 54.01 & 47.62 & 44.21 & 48.61 & 64.68 & 67.27 & 67.63 & 66.68 \\
\hline & \multirow{3}{*}{$\begin{array}{l}\text { Without } \\
\text { Farmyard } \\
\text { manure }\end{array}$} & $40 \mathrm{~kg} \mathrm{~N} / \mathrm{fed}$ & 56.31 & 50.00 & 44.29 & 50.20 & 55.77 & 59.66 & 60.26 & 58.56 \\
\hline & & $60 \mathrm{~kg} \mathrm{~N} / \mathrm{fed}$ & 57.86 & 52.38 & 45.60 & 51.94 & 56.43 & 59.76 & 60.86 & 59.02 \\
\hline & & $80 \mathrm{~kg} \mathrm{~N} / \mathrm{fed}$ & 60.95 & 54.76 & 47.50 & 54.40 & 56.67 & 59.92 & 61.81 & 59.47 \\
\hline & & Mean & 58.37 & 52.38 & 45.80 & 52.18 & 56.29 & 59.78 & 60.98 & 59.02 \\
\hline \multirow{8}{*}{$\begin{array}{l}2^{\text {nd }} \\
\text { season }\end{array}$} & \multirow{3}{*}{$\begin{array}{l}\text { With } \\
\text { Farmyard } \\
\text { manure }\end{array}$} & $40 \mathrm{~kg} \mathrm{~N} / \mathrm{fed}$ & 52.86 & 46.43 & 43.81 & 47.70 & 64.13 & 65.80 & 66.56 & 65.50 \\
\hline & & $60 \mathrm{kgN} / \mathrm{fed}$ & 55.00 & 48.81 & 45.71 & 49.84 & 64.78 & 65.99 & 67.03 & 65.93 \\
\hline & & $80 \mathrm{~kg} \mathrm{~N} / \mathrm{fed}$ & 56.66 & 50.00 & 46.67 & 51.11 & 66.10 & 67.90 & 68.99 & 67.77 \\
\hline & & Mean & 54.84 & 48.41 & 45.40 & 49.55 & 65.00 & 66.56 & 67.53 & 66.42 \\
\hline & \multirow{3}{*}{$\begin{array}{l}\text { Without } \\
\text { Farmyard } \\
\text { manure }\end{array}$} & $40 \mathrm{~kg} \mathrm{~N} / \mathrm{fed}$ & 57.62 & 52.38 & 45.48 & 51.83 & 55.54 & 58.65 & 59.81 & 58.00 \\
\hline & & $60 \mathrm{~kg} \mathrm{~N} / \mathrm{fed}$ & 60.00 & 53.57 & 46.79 & 53.45 & 55.66 & 59.31 & 60.13 & 58.37 \\
\hline & & $80 \mathrm{~kg} \mathrm{~N} / \mathrm{fed}$ & 60.71 & 55.95 & 48.69 & 54.12 & 57.67 & 60.10 & 61.13 & 59.63 \\
\hline & & Mean & 59.44 & 53.97 & 46.99 & 53.13 & 56.29 & 59.35 & 60.36 & 58.66 \\
\hline
\end{tabular}

\section{Water use efficiency:}

Water use efficiency affected by irrigation intervals, farmyard manure and fertilization $\mathrm{N}$ levels. Data in Table ( 5 ) show that the water use efficiency increases by decreasing water irrigation. The highest value were 64.31 and $63.94 \mathrm{~kg} / \mathrm{cm}$ under irrigation intervals 50 day in $1^{\text {st }}$ and $2^{\text {nd }}$ seasons, followed by 63.53 and $62.96 \mathrm{~kg} / \mathrm{cm}$ under irrigation every 40 day and the lowest value under interval 30 day. These agreement with Hefnawy and Wahba( 2003 ).

Farmyard manure effected on water use efficiency, with farmyard manure, water use efficiency increased by 11.49 and $11.59 \%$ 
compared to without farmyard manure in $1^{\text {st }}$ and $2^{\text {nd }}$ seasons, respectively.

Water use efficiency affected by fertilization $\mathrm{N}$ levels, by increase $\mathrm{N}$ levels water use efficiency increase ,highest values were 63.56 and 63.65 $\mathrm{kg} / \mathrm{cm}$ under $80 \mathrm{~kg} \mathrm{~N} /$ fed. followed by 62.95 and $62.55 \mathrm{~kg} / \mathrm{cm}$ under $60 \mathrm{~kg} \mathrm{~N} / \mathrm{fed}$. and 62.06 and $61.75 \mathrm{Mag} / \mathrm{fed} .40 \mathrm{~kg} \mathrm{~N} / \mathrm{fed}$ in $1^{\text {st }}$ and $2^{\text {nd }}$ seasons respectively.

Data in Table (5) show highest values were 68.69 and $68.99 \mathrm{~kg} / \mathrm{cm}$. due to interaction between irrigation every 50 day (I3), with farmyard manure and Fertilization level $80 \mathrm{~kg} \mathrm{~N} / \mathrm{fed}$. Lowest values ( 55.76 and $55.54 \mathrm{~kg} / \mathrm{cm}$ ) due to interaction between irrigation every 30 day ,without farmyard manure and fertilization level $40 \mathrm{~kg} \mathrm{~N} / \mathrm{fed}$.

\section{CONCLUSION}

The objective of this research study the effect of nitrogen fertilizers levels, with and without adding farmyard manure under three irrigation intervals on wheat yield and yield components, straw and water use efficiency. The results showed that :

The treatment of irrigation every 30 days, the plant height, straw yield ( ton /fed ), spike height .No. of grains /spike and grain yield ( $\mathrm{Mg} / \mathrm{fed})$ were increased . the water use efficiency was decreased .

Using farmyard manure increase the plant height, straw yield ( ton/fed ) ,spike height .No. of grains /spike, grain yield ( $\mathrm{Mg} / \mathrm{fed})$ and water use efficiency compared to without farmyard manure .

Increasing fertilization $\mathrm{N}$ levels increase both plant height, straw yield (ton/fed) ,spike height .No. of grains /spike, grain yield (Mg/fed) and water use efficiency were increased .

In order to maximize wheat yield and its components and to use the irrigation water efficiently, under Gemmeiza area conditions, it is recommended to irrigation interval 30 days, with farmyard manure and fertilization level $80 \mathrm{~kg} \mathrm{~N} / \mathrm{fed}$. 


\section{REFERENCES}

Abou- Khadrah, S. H., S. A. Abd El-Hafez, F. A. Sorour and A. Z. ElBably ( 1999) Effect of soil moisture stress on wheat production, its components and Nutrient uptake $.3^{\text {rd }}$ Conf. of on Farm Irri. And Agroclim. Giza Egypt paper No. 47

Ali,S.A. ( 1997 ) Effect of some agricultural practices on growth ., Yield and yield components of wheat. PP.90-132. Ph.D. Thesis, Fac. Agric., El-Menia Univ., Egypt .

Ali,S.A.I.,A.E-Sherbieny,S.M.DahdouhandM.M.Mostaffa(2008)

Nitrogen fertilization management for wheat TRITICUM AESTIVURM ) Irrigated with El- Salam canal water South East Qantra, Sinai .Zagazig J. Aric. Res., Vol. 35 ( 5 ) : 1083- 1105

Allam , S. A. ( 2005) Effect of some preceding summer crops and application time of Micronutrients on growth, yield and yield components of wheat ( Triticum Aestivumvulgare L.)in sandy soils . Egypt . J. App.Sci., 16 ( 3 ): 107- 125.

AnureetkaurPannu and Buttar (2010) Impact of nitrogen application on the Performance of wheat ( Triticumaestivum L. ) and nitrogen use efficiency Under different dates of sowing .Indian J. of Agron. , 55 ( 1$): 40-43$.

El-Sayed m. S. Gheith , Ola Z. El-badry and S. A. Wahid ( 2013) Response of growth And straw yield of some wheat genotypes to sowing dates and nitrogen Levels Zagzig J .Agric. Res., Vol. 40( 5 : 809-815.

Gehan A. M. Amin , H. G. Geweifel , M. A. Gomaa and T,A.Nour (2011) Effect of sowing method micronutrients and nitrogen fertilizer levels on wheat yield under sandy soil conditions. Zagazig J .Agric. Res. Vol. 38 (2) 233- 248. 
James ,L.C.(1988). Principles of farm irrigation system design . John Wiley \&Sons New york Chichester Brisbane Toronto Singapore, $410 \mathrm{p}$.

Javaid Iqbal, Khizer Hayat and Safdar Hussain ( 2012 ). Effect of sowing dates and nitrogen levels on yield and yield components of wheat ( Triticum aestivum L. ) Pakistan J . OF Nutri., 11 (7) : 531536.

Hefnawy ,F. A. and M. F. Wahba ( 2003) .Effect of water stress in late in late growth Stages of some wheat cultivars .J.Agric. Sci. Mansoura Univ., 28( 2) : 729- 745.

Michael ,A. M. (1978) Irrigation theory and practice. Viskas Pub. House PVTLTD: New Delhi. J. 83.

Moussa , A. M. and H.H. Abdel- Maksoud ( 2004 ) Effect of soil moisture regime on Yield and its components and water use efficiency for some wheat cultivars. Annais Agric. Sci. Ain Shams Univ., Cairo , 49 ( 2) 515-530 .

Qi WangFengruili ,Enhe Zhang, Guan Li and ManreanVence (2012) The effect of irrigation and nitrogen application rates on yield of spring wheat( Longfu-920) and water use efficiency and nitrate accumulation in soil . Australian J of crop Sci. , 6 ( 4) : 662- 672.

Seiling K., C. Stahl , C. Winkelmann and Christen ( 2005 ) Growth and yield of winter wheat in the first 3 years of a monoculture under varying $\mathrm{N}$ fertilization in NW Germany . Europ. J. Agron .,22: 7184.

Tammam, A. M. and M. B. Tawfils ( 2004) Effect of sowing dates and nitrogen fertilizer levels in relation to yield and yield components of durum wheat (Triticumturgidumvar. durum) under upper Egypt environments , J. Agric. Sci., Mansoura Univ., 29 (10) : 5431 5442. 


\section{الملخص العربي}

\section{ادارة مياة الرى السطحى على محصول القمح فى الوادى القديم}

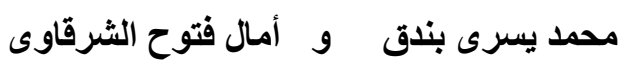



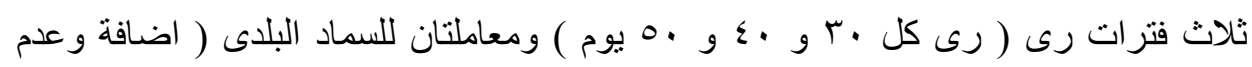

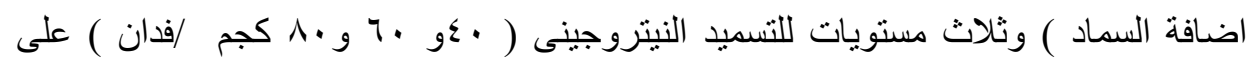

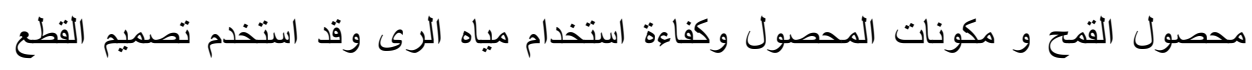

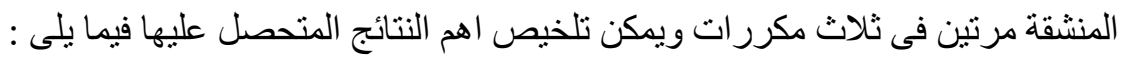

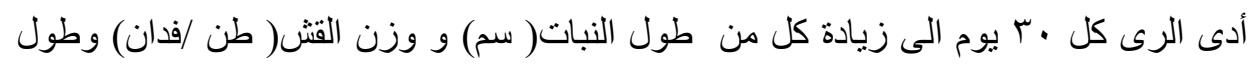

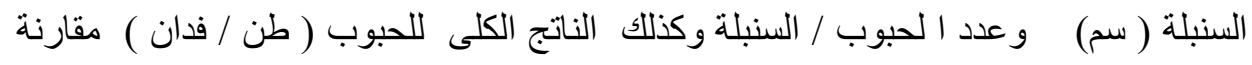

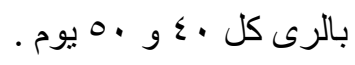

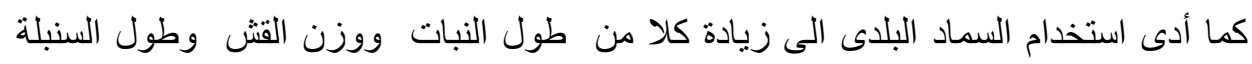

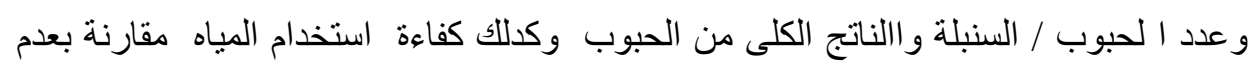



و أدى زيادة مستوى التسميد النيتروجين الى زيادة كلا من طول النبات و وزن القش وطول وطول

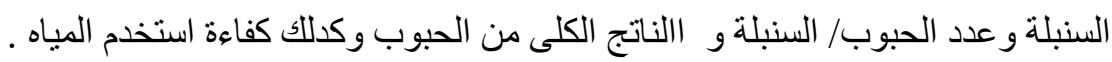



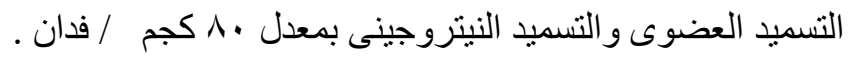

*معهد بحوث الهندة الزراعية ـ الدقى .جيزة ـ مصر. 